\title{
Development and Physico-chemical analysis of digestive pills from Makoi (Solanum nigrum).
}

\author{
Bimal Bibhuti (Advisor- Er. K. L. Bala) \\ Department of Food Process Engineering, Vaugh School of Agricultural Engineering and Technology \\ Sam Higginbottom Institute of Agriculture, Technology and Sciences Allahabad
}

\begin{abstract}
Solanum nigrum belongs to family Solanaceae. Blacknightshade \& Makoi are the common name for it. The chemical constituents commonly found in Solanum nigrum are glycoalkaloids, glycoproteins, polysaccharides, polyphenolic compounds such as gallic acid, cathechin, protocatechuic acid, caffeic acid, epicatechin, rutin etc. Solanum nigrum has very much importance as a medicinal plant. Root, whole plant and leaves are used but fruits of black colour are not used as they possess toxicity, therefore they are not used for medicinal purposes. Reddish- brown coloured fruits are used for edible purpose. It has been also extensively used in traditional medicine In India and other parts of world to cure liver disorders, digestion, chronic skin ailments, inflammatory conditions, painful periods, fevers, diarrhoea, eye disease, hydrophobia etc. Extracts prepared with using spices condiments exhibited stomach disorders and also improved digestion activity as compared to other digestive pills.
\end{abstract}

Keywords: Solanum nigrum, medicinal, liver disorders, digestion, condiments, digestive pills.

\section{Introduction}

India is the largest producer of medicinal plants and brightly called as the "Botanical garden of the world". Plant derived drugs even today remain important resource especially in developing countries to combat serious diseases. Approximately $62-80 \%$ of world's population still relies on traditional medicines for the treatment of common illness (WHO 2002, Zhang 2004).

S. nigrum is an important ingredient in traditional Indian medicines. Infusions are used in dysentery, stomach complaints, and fever. In India, the berries are casually grown and eaten, but not cultivated for commercial use. The quest to manufacture foods for healthy benefits is an underpinning goal of the modern food industry. Food processing has evolved to carryout steps for the controlled destruction of natural food structures. These steps facilitate separation of valuable components from the original matrix in which they are embedded. The separated ingredients are then converted into recognizable processed foods with desirable's textural \& sensorial properties by application of one or more processing steps (Aguilera \& Stanley 1999). Recent evidence indicates that how the food structure breaks down during gastric digestion significantly affects the rate of uptake of nutrients in the gastrointestinal (GI) tract (Armand et al. 1999, Jarvi et al. 1995).

The digestion process has been well studied in terms of secretion of gastric fluids, enzymatic breakdown of fats, proteins and carbohydrates, and molecular and ionic transport across the intestinal epithelium. However, there remains a notable lack of understanding about the food disintegration kinetics and the extraction of small molecules from complex food structures in the gastric environment. The rate of food disintegration in stomach is a key factor influencing emptying rate and subsequently affecting absorption of nutrients in the intestine. Faster disintegration and emptying of drug tablets is responsible for the faster absorption of drug ingredients in the intestine (Kelly and et al. 2003).

The stomach contraction, particularly terminal antral contraction, imposes a considerable mechanical destructive force on food particulates and thus is crucial on the disintegration of solids. Researchers have measured contraction forces present in the stomach ranging from $0.2 \mathrm{~N}$ to $2 \mathrm{~N}$ (Vassallo and $\boldsymbol{e}$ t al. 1992, Camillieri and Prather 1994, Kamba and et al. 2000, 2001).

Findings from this research will provide an improved understanding of the interaction of the food matrix and active ingredients during gastric digestion. The computational modeling of the human stomach will predict the kinetics of disintegration of a food matrix under known physiological conditions of the stomach. These findings should provide new information for the food processing industry to develop structured foods for healthful benefits and develop strategies for controlled release of food nutrients at desired sites in the GI tract. The anticipated information will enhance understanding of the stomach emptying of foods to develop approaches to control it. Control of gastric emptying is essential for ensuring optimal digestion. The rate of food disintegration in the stomach appears to be a key factor influencing emptying rate and subsequently affecting absorption of nutrients in the intestine. The potential for modulation of the rate of gastric emptying to control obesity and diabetic patients is now being explored vigorously by the pharmaceutical industry (Rayner and $\boldsymbol{e t}$ al. 2001). Study of gastric disintegration of foods should also help our understanding of the interactions between 
food and drugs during digestion. The disintegration activity of a drug is substantially affected by the presence of food components. Thus the understanding of food disintegration should help improve the control of pill dissolution in stomach.

Kakamachi (Solanum nigrum) is widely described in the Ayurrvedic classics \& also have references in Vedas. This herb has its own ertho-medical importance since it plays a significant role in the treatment of various diseases. It is having both curative \& nutritive value. It is used as single drug \& in compound formulations. In this research, we use different ingredients along with Solanum nigrum to increase their pharmological properties, therapeutic or dietarg utility indigestion. Hence the project is carried out under the above objectives.

\section{Materials and Methods}

This chapter deals with the description of various materials and methods which was used to accomplish the experimental work done to attain the desired objectives of the work entitled, Development and Physicochemical analysis of digestive pills from Makoi (Solanum nigrum). The experimental technique, materials which was used in this study and the associated methodology for product development and their Physicochemical analysis was elaborated in this chapter. The experimental plan was shown in the table below with different variables, levels and description.

Table 2.1 Experimental Plan

\begin{tabular}{|l|l|l|l|}
\hline Sr. No. & Variables/ Parameters & Levels & Description \\
\hline 1 & Product & 1 & Digestive Pills \\
\hline 2 & Ingredients & 8 & $\begin{array}{l}\text { Makoi (Solanum nigrum), Hing, Pepper longum \& Tailed } \\
\text { pepper, Ajwain, Jeera, Black Salt, Imli Paste and Artificial } \\
\text { sweetner. }\end{array}$ \\
\hline 3 & Treatment & $1 \times 5$ & $\mathrm{~T}_{0}, \mathrm{~T}_{1}, \mathrm{~T}_{2}, \mathrm{~T}_{3}, \mathrm{~T}_{4}$ \\
\hline 4 & Replication & 3 & $\mathrm{R}_{1}, \mathrm{R}_{2}, \mathrm{R}_{3}$ \\
\hline 5 & Physico-chemical Analysis & 7 & $\begin{array}{l}\text { Moisture, Protein, Fat, Total Ash, Crude fibre, Carbohydrate } \\
\text { and Calories. }\end{array}$ \\
\hline
\end{tabular}

Table 2.2 Experimental Design

\begin{tabular}{|l|l|l|l|l|l|}
\hline $\begin{array}{l}\text { Treatments } \\
\text { Ingredients }\end{array}$ & $\mathbf{T}_{\mathbf{0}}$ & $\mathbf{T}_{\mathbf{1}}$ & $\mathbf{T}_{\mathbf{2}}$ & $\mathbf{T}_{\mathbf{3}}$ & $\mathbf{T}_{\mathbf{4}}$ \\
\hline Makoi & $12 \%$ & $20 \%$ & $24 \%$ & $25 \%$ & $26 \%$ \\
\hline $\begin{array}{l}\text { Pepper longum \& Tailed } \\
\text { pepper }\end{array}$ & $5 \%$ & $4 \%$ & $3 \%$ & $3 \%$ & $3 \%$ \\
\hline Hing & $1 \%$ & $1 \%$ & $1 \%$ & $1 \%$ & $1 \%$ \\
\hline Artificial sweetner & $12 \%$ & $12 \%$ & $14 \%$ & $15 \%$ & $15 \%$ \\
\hline Ajwain & $20 \%$ & $8 \%$ & $8 \%$ & $8 \%$ & $7 \%$ \\
\hline Jeera & $15 \%$ & $10 \%$ & $10 \%$ & $8 \%$ & $8 \%$ \\
\hline Black Salt & $10 \%$ & $15 \%$ & $15 \%$ & $15 \%$ & $15 \%$ \\
\hline Imli Paste & $25 \%$ & $25 \%$ & $25 \%$ & $25 \%$ & $25 \%$ \\
\hline
\end{tabular}

From the above formula, the development of product from different treatments were done and in these treatments the treatment $T_{1}$ was widely accepted by the judgers and the further experiments were carried-out by using this formula. According to the judger's confirmation for treatment $T_{1}$, the alteration in moisture were calculated and by this alteration the total effect on the Physico-chemical properties of the developed product was estimated (as $R_{1}, R_{2}$ and $R_{3}$ ) and the mean value of the data for the product was selected which were given as follows. All the Physico-chemical values were calculated as per $100 \mathrm{~g}$ of the developed product.

Table 2.3 Experimental Design for Developed Product

\begin{tabular}{|l|l|l|l|l|}
\hline $\begin{array}{l}\text { Replication } \\
\text { Physico-chemical properties }\end{array}$ & $\mathbf{R}_{\mathbf{1}}$ & $\mathbf{R}_{\mathbf{2}}$ & $\mathbf{R}_{\mathbf{3}}$ & Mean Value \\
\hline Moisture & $22.43 \%$ & $16.23 \%$ & $15.02 \%$ & $17.89 \%$ \\
\hline Protein & $0.82 \%$ & $0.85 \%$ & $0.86 \%$ & $0.84 \%$ \\
\hline Fat & $1.95 \%$ & $1.97 \%$ & $1.98 \%$ & $1.97 \%$ \\
\hline Total Ash & $2.4 \%$ & $2.6 \%$ & $2.8 \%$ & $2.6 \%$ \\
\hline Crude Fibre & $1.62 \%$ & $1.60 \%$ & $1.59 \%$ & $1.60 \%$ \\
\hline Carbohydrate & $72.4 \%$ & $78.35 \%$ & $79.34 \%$ & $76.7 \%$ \\
\hline Calories & $310.43 \mathrm{Kcal}$ & $334.53 \mathrm{Kcal}$ & $338.62 \mathrm{Kcal}$ & $327.89 \mathrm{Kcal}$ \\
\hline
\end{tabular}




\subsection{Methods}

\subsubsection{Experimental procedure}

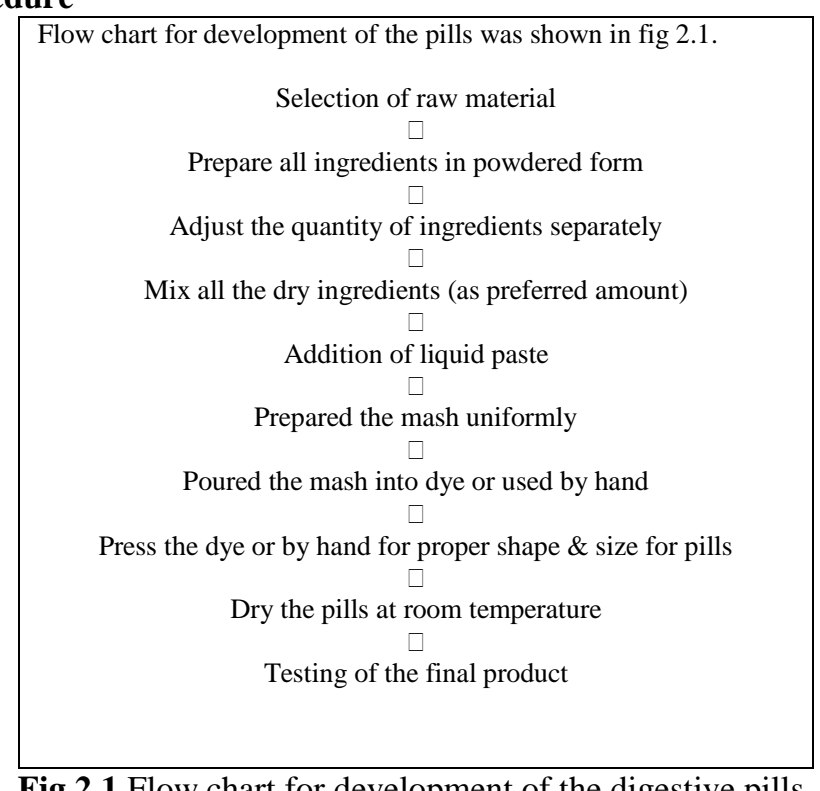

All the ingredients were used in the development of digestive pills were purchased in bulk from local market at Allahabad and care was taken from duplicity. After that they were prepared in powdered form before mixing and then weighed in the suitable amount as required during preparation. Then after the dry ingredients were mixed uniformly for the development of digestive pills. After that addition of liquid paste of Imli was added to dry ingredients which provided good consistency and texture to the digestive pills. After addition of liquid paste into the dry ingredients, the whole mass was mashed uniformly and by the help of dye or by hand, suitable shape was done to it and then after development, the pills were checked thoroughly for their uniformity and estimated their Physico-chemical analysis in the laboratory.

\section{Result and Discussion}

This chapter deals with the findings of the study and effect of developed pills with different spices condiments, on the parameters such as Physico-chemical evaluation were studied.

\subsection{Development of digestive pills}

The product development was done by the panel of judges with the help of nine point hedonic scale. At first, the different treatments were done with the help of ingredients from experimental design table no. 3.2 and product was developed. The treatments were named as $T_{0}, T_{1}, T_{2}, T_{3}, T_{4}$. In these developed products, the treatment $T_{1}$ was good according to the judgers so we selected the treatment $T_{1}$ for further replication i.e. $R_{1}, R_{2}$ and $\mathrm{R}_{3}$. and adjusted the moisture $\%$ by treating the sample in hot air oven (i.e. for $\mathrm{R}_{2}$ the temperature and time combination was $55^{\circ} \mathrm{C}$ for 5 minutes and for $\mathrm{R}_{3}$, it was $60^{\circ} \mathrm{C}$ for 5 minutes) and the mean moisture $\%$ value of the developed digestive pills was selected. During the development of product, the Physico-chemical properties were also changed in alteration in moisture. These were summarized in the following section. The ratio was taken for the development of digestive pills was mentioned above in the table and also their Physico-chemical evaluation was shown as follows with their suitable graph.

\subsection{Physico-chemical properties of developed digestive pills}

The effects on Physico-chemical properties of developed digestive pills were presented below in table. It was found that, all the Physico-chemical properties of the digestive pills were not affected in controlled moisture at ambient temperature.

Table 3.1 Effect of Physico-chemical properties on developed digestive pills.

\begin{tabular}{|l|l|l|l|l|l|l|l|}
\hline $\begin{array}{l}\text { Physico-chemical } \\
\text { properties } \square \\
\text { Parameter } \square\end{array}$ & Moisture & Protein & Fat & $\begin{array}{l}\text { Total } \\
\text { Ash }\end{array}$ & $\begin{array}{l}\text { Crude } \\
\text { Fibre }\end{array}$ & Carbohydrate & Calories \\
\hline Mean Value of Replications & $17.89 \%$ & $0.84 \%$ & $1.97 \%$ & $2.6 \%$ & $1.60 \%$ & $76.7 \%$ & $327.09 \mathrm{Kcal}$ \\
\hline
\end{tabular}




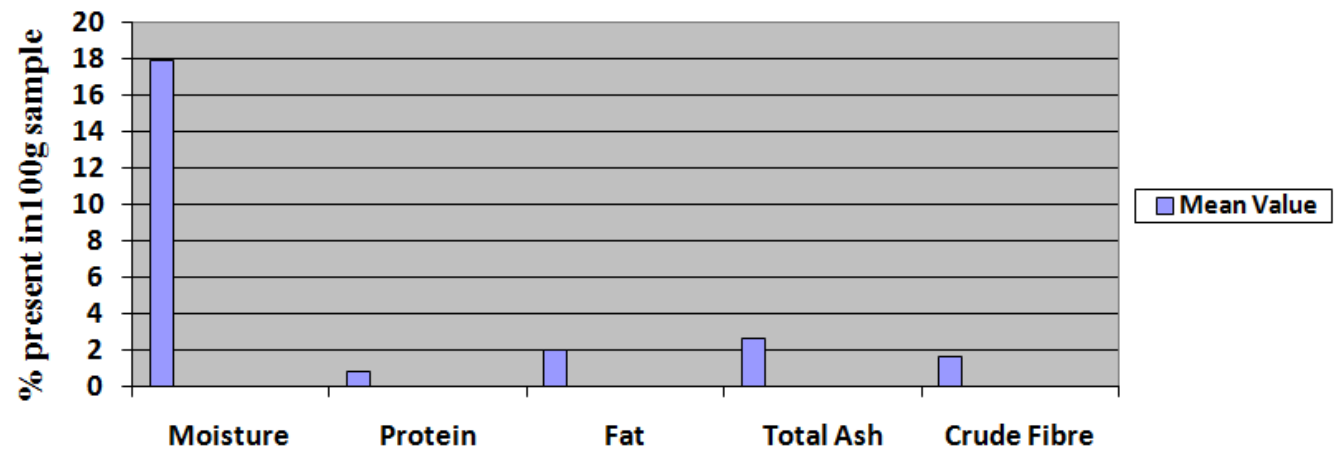

Physico-chemical properties

Fig. 3.1 Effect of Physico-chemical properties on developed digestive pills.

\subsection{Summary}

\section{Summary and Conclusion}

This present investigation on development and Physico-chemical analysis of digestive pills from Makoi was undertaken in the Department of Food Process and Engineering, Vaugh school of Agricultural Engineering and Technology, Sam Higginbottom Institute of Agriculture, Technology and Sciences Allahabad. In the present investigation efforts were made to develop the digestive pills with incorporation of other digestive ingredients which also helped the sensory characteristics to the developed digestive pills. During the Physico-chemical analysis it was found that the developed digestive pills had moisture (17.89\%), protein $(0.84 \%)$, fat $(1.97 \%)$, total ash $(2.6 \%)$, crude fibre $(1.60 \%)$, carbohydrate $(76.7 \%)$ and calories $(327.09 \mathrm{Kcal})$. It was also found from Anova that the variation between the product treatments was non-significant and the variation within the product replications was significant.

\subsection{Conclusion}

From this preliminary investigation and research, it has been concluded that the development and Physico-chemical properties of developed digestive pills have good source of protein, fat, crude fibre, carbohydrate and calories which also lies under the dietary limit of daily intake. The developed digestive pills have found satisfactory in the stomach digestion after testing their physic-chemical analysis and has acceptable; while the extract mechanism of action remains to be elucidated in many cases of disease. The Makoi (Solanum nigrum) has wide-ranging Therapeutic properties needs to be investigated in well-designed studies and further research is in process to find more uses of Solanum nigrum (Hawkes and Edmonds, 1972; Kajiaet al., 1997; Landolt, 1977).

[1]. Agrawal KR, Lucas PW, Prinz JF, Bruce IC. (1997). Mechanical properties of foods responsible for resisting food breakdown in the human mouth. Arch Oral Biol42, 1-9.

[2]. Aguilera JM, Stanley DW. (1999). Microstructural principles of food processing and engineering. Aspen Publishers Inc., Maryland, USA.

[3]. Ali NS, Singh K, Khan MI, Rani S. (2010). Protective effect of ethanolic extracts of Solanum nigrum on the blood sugar of albino rats. IJPSR. 1(9); 97-99.

[4]. Amarsingham, R D, Bisset N G, Millard A H and Woods M C (1964).A phytochemical survey of Malaya-III, Alkaloids and saponins. Economic Botany, 18, 270-278.

[5]. Arunachalam G, Subramanian N, Pazhani GP, Karunanithi M, Ravichandran V. (2009). Evaluation of anti-inflammatory activity of methanolic extract of Solanum nigrum (Solanaceae).-Iranian Journal of Pharmaceutical Sciences Summer 5(3), 151156.2

[6]. Atanu FO, Ebiloma UG, Ajayi EI (2011).A review of the pharmacological aspects of Solanum nigrum Linn. Biotechnology and Molecular Biology Review. 6(1), 001-007.

[7]. Chifundera K. (1998). Livestock diseases and the traditional medicine in the Bushi area, Kivu province, Democratic Republic of Congo. Afr Study Monogr, 19:13-33.

[8]. Cooper MR, Johnson AW. (1984). Poisonous Plants in Britain and their Effects on Animals and Man. London. H.M.S.O., 219220.

[9]. Dhellot JR, Matouba E, Maloumbi MG, Nzikou JM, Dzondo1 MG, Linder M, Parmentier M, Desobry S. (2006). Extraction and nutritional properties of Solanum nigrum L. Seed oil. African Journal of Biotechnology. 5(10), 987-991.

[10]. Elhag RAM, Badwi MAE, Bakhiet AO, Galal M. (2011). Hepatoprotective activity of Solanum nigrum extracts on chemically induced liver damage in rats. Journal of Veterinary Medicine and Animal Health. 3(4), 45-50.

[11]. F. O. Atanu, U. g. Ebiloma and E. I. Ajayi, 2010. A Review of The Pharmacological Aspects of Solanum nigrum Linn. .Biotechnology and molecular Biology Review Vol. 6(1), pp. 001-007.

[12]. Hamil F A, Apio S, Mubiru N K, Bukenya-Ziruba R, Mosanyo M and Magangi Owe, (2003). Traditional herbal drugs of southern Uganda, II. Literature analysis and antimicrobial assays. Journal of Ethnopharmacology, 84: 57-78. 
[13]. Harborne J B, Phytochemical methods. (1984). A guide to modern techniques of plant analysis. Chapman and Hall, London, New York, ed. II: 24-25.

[14]. Hawkes, J. G. and J. M. Edmonds, 1972. Solanum L. In; Tut, T. G., V. H. Heywood, N. a. Burges, D. M. Moore, D. H. Valentine, S. M. Walter and D. A. Webb (Eds.), in Flora European University Press, Cambridge, 3; 197-199.

[15]. Heo KS, Lee SJ, Ko JH, et al. (2004). Glycoprotein isolated from Solanum nigrum L. inhibits the DNA-binding activities of NFkappaB and AP-1, and increases the production of nitric oxide in TPA-stimulated MCF-7 cells. Toxicolin Vitro, 18:755-763.

[16]. Hussain; A. O. D., Virmani and S. P. Pople, 1992. Dictionary of Indian Medicinal Plants. Central Institute of Medical and Aromatic plants, Lucknow, pp: 35.

[17]. Jabar Z. K. Khattak and et al., 2012. Solanum nigrum as potent Therapy: A review. British Journal of pharmacology and Toxicology 3(4):185-189.

[18]. Jain R, Sharma A, Gupta S, Sarethy IP, Gabrani R (2011). Solanum nigrum: Current Perspectives on Therapeutic Properties. Alternative Medicine Review, LLC. 16 (1), 78-85.

[19]. Jainu, M. and C.S.S. Devi (2004). Antioxidant effect of methanolic extract of Solanum nigrum berries on aspirin induced gastric mucosal injury. Indian J. Clin. Biochem. 19: 65-70.

[20]. Joo HY, Lim K, Lim KT. (2009). Phytoglycoprotein (150 kDa) isolated from Solanum nigrum Linne has a preventive effect on dextran sodium sulfate-induced colitis in A/J mouse. J Appl Toxicol, 29:207-213.

[21]. Kambizi L, Afolayan AJ (2001). An ethnobotanical study of plants used for the treatment of sexual transmitted diseases (njovhera) in Guruve District, Zimbabwe. J Ethnopharmacol. 77(1), 5-9.

[22]. Karmakar UK, Tarafder UK, Sadhu SK, Biswas NN, Shill MC. (2010). Biological investigations of dried fruit of Solanum nigrum Linn. .S. J. Pharm. Sci. 3(1), 38-45.

[23]. Kaushik D, Jogpal V, Kaushik P, et al. (2009).Evaluation of activities of Solanum nigrum, fruit extract. Arch Appl Sci Res., 1:4350 .

[24]. Kelly K, O'Mahony B, Lindsay B, Jones T, Grattan TJ, Rostami-Hodjegan A, Stevens HN, Wilson CG. (2004). Comparison of the rates of disintegration, gastric emptying, and drug absorption following administration of a new and a conventional paracetamol formulation, using $\gamma$ scintigraphy. Pharm Res 20(10):1668-73.

[25]. Kojia, M., R. Popovia and B. Karadyia, 1997. Vaskularne biljke Srbiyekaoin dikatoristanista, Institut zaistrayivanja u polyoprivedi "Srbija" and Institut zabioloskai strayivanja "sinisa Stankovia", Beograd.

[26]. Lee KR, Kozukue N, Han JS, et al. (2004). Glycoalkaloids and metabolites inhibit the growth of human colon (HT29) and liver (HepG2) cancer cells. J Agric Food Chem, 52:2832-2839.

[27]. Li J, Li QW, Gao DW, et al. (2009). Antitumor and immune modulating effects of polysaccharides isolated from Solanum nigrum Linne. Phytother Res, 23:1524-1530.

[28]. Parveen, Upadhyay B, Roy S, Kumar A. (2007). Traditional uses of medicinal plants among the rural communities of Churu district in the! ar Desert, India. J Ethnopharmacol, 113:387-399.

[29]. Patels S, Gheewala N, Suthar A, Shah A. (2009). In-vitro cytotoxicity activity of Solanum nigrum extracts against Hela cell lines and Vero cell lines. International journal of pharmacy and pharmaceutical sciences. 1(1), 38-46.

[30]. Purohit S S and Vyas S P, (2004). Medicinal plants cultivation a scientific approach including processing and financial guidelines. 1st edition. Publishers Agrobios, Jodhpur, India: 1-3.

[31]. R. Paul Singh, Distinguished Professor of Food Engineering. Role of Food Material Properties and disintegration Kinetics in gastric digestion- A quest for Foods for Healthy Benefits: 1-13.

[32]. Rajani Chauhan, Km. Ruby and et al., 2012. Solanum nigrum with Dynamic Therapeutic Role; A Review. International Journal of Pharmaceutical Sciences Review and Research; 15(1), $\mathrm{n}^{\circ}$ 14, 65-71.

[33]. Ramya Jain, Anjali sharma and et al., 2011. Solanum nigrum: Current perspectives on Therapeutic Properties. Alternative Medicine review; Volume 16, number 1, 78-85.

[34]. Ravi V, Saleem TSM, Maiti PP, Gauthaman K, Ramamurthy J. (2009). Phytochemical and pharmacological evaluation of Solanum nigrum Linn. African Journal of Pharmacy and Pharmacology. 3(9), 454-457.

[35]. Rawani A, Ghosh A Chandra G.n (2010). Mosquito larvicidal activities of Solanum nigrum L. leaf extract against Culexquinquefasciatus. Parasitol Res. 107, 1235-1240.

[36]. Rayner CK, Samsom M, Jones KL, Horowitz M. 2001. Relationships of upper gastrointestinal motor and sensory function with glycaemic control. Diabetes Care 24; 371-81.

[37]. Schilling EE, Ma QS, Andersen RN. (1992). Common names and species identification in black nightshades, Solanumsect. Solanum (Solanaceae). Econ Bot, 46:223-225.

[38]. Sharma YK, Singh H, Mehra BL. (2004). Hepatoprotective effect of few Ayurvedic herbs in patients receiving antituberculus treatment. Indian J Traditional Knowledge, 3:391-396.

[39]. Sikdar M, Dutta U. Traditional phytotherapy among the Nath people of Assam. Entno- Med 2008; 2; 39-45.

[40]. Sridhar TM, Josthna P, Naidu CV. (2011). In vitro antibacterial activity and phytochemical analysis of Solanum nigrum (Linn.) An important antiulcer medicinal plant. Journal of Experimental Sciences. 2(8), 24-29.

[41]. Sridhar TM, Josthna P, Naidu CV. (2011). Antifungal activity, phytochemical analysis of Solanum nigrum (L.)- An important antiulcer medicinal plant. Journal of Ecobiotechnology. 3(7), 11-15.

[42]. Sultana S, Perwaiz S, Iqbal M, Athar M. (1995). Crude extracts of hepatoprotective plants, Solanum nigrum and Cichoriuminty businhibit free radical-mediated DNA damage. J Ethnopharmacol, 45:189-192.

[43]. Sweta Prakash and Ashok K. Jain, 2011. Antifungal Activity and Preliminary Photochemical Studies of Leaf Extracts of Solanum nigrum Linn. International Journal of Pharmacy and Pharmaceutical Sciences; 352-355.

[44]. Vassallo MJ, Camilleri M, Prather CM, Hanson RB, Thomforde GM. (1992). Measurement of axial forces during emptying from the human stomach. Am J Physiol Gastrointest Liver Physiol.263:G230-9.

[45]. Venkatesan D, Karrunakaran CM. (2010). Antimicrobial activity of selected Indian medicinal plants. Journal of Phytology. 2(2); $44-48$. 